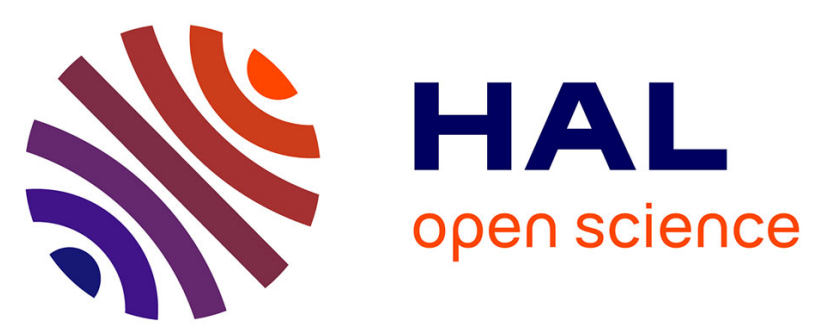

\title{
Could occupation duration be related to the diversity of faunal remains in Mesolithic shell middens along the European Atlantic seaboard?
}

\author{
Catherine Dupont
}

\section{- To cite this version:}

Catherine Dupont. Could occupation duration be related to the diversity of faunal remains in Mesolithic shell middens along the European Atlantic seaboard?. Quaternary International, 2016, 407 (Part B), pp.145 - 153. 10.1016/j.quaint.2016.01.039 . hal-01376220

HAL Id: hal-01376220

https://hal-univ-rennes1.archives-ouvertes.fr/hal-01376220

Submitted on 10 Oct 2016

HAL is a multi-disciplinary open access archive for the deposit and dissemination of scientific research documents, whether they are published or not. The documents may come from teaching and research institutions in France or abroad, or from public or private research centers.
L'archive ouverte pluridisciplinaire HAL, est destinée au dépôt et à la diffusion de documents scientifiques de niveau recherche, publiés ou non, émanant des établissements d'enseignement et de recherche français ou étrangers, des laboratoires publics ou privés. 


\title{
Could occupation duration be related to the diversity of faunal remains in Mesolithic
}

\section{shell middens along the European Atlantic seaboard?}

\author{
Catherine Dupont \\ CNRS UMR 6566 CReAAH, University of Rennes 1, Rennes 2, Nantes, Mans and Ministère of the \\ Culture; Building 24-25 Campus of Beaulieu, University of Rennes 1, 263 avenue Leclerc General, \\ CS 74205, 35042 Rennes Cx, France; catherine.dupont@univ-rennes1.fr
}

\begin{abstract}
In order to define the Mesolithic populations that came to settle on the European Atlantic seaboard, it is essential to assess the duration and continuity of human occupation. Although our knowledge of the geographical distribution of these populations is largely truncated by archaeological bias, the presence of more than 240 Mesolithic shell middens along the European Atlantic coast enables us to establish an overview of the published data on the dwelling patterns (seasonal, permanent, recurrent or limited in time) of these groups of maritime hunter-gatherers. A review of the literature shows that information on human occupations is lacking for many known Mesolithic shell middens. Moreover, the data leading to the identification of settlement patterns prove to be very heterogeneous from one site to another. Marine molluscs play a special role among the artefacts used to define the attraction of human populations for the coast, and help us to understand settlement. Although molluscs represent a major component of Mesolithic shell middens, it has taken several decades for the analysis of these faunal remains to be considered from the outset in excavations. One of the questions addressed here is whether the diversity of faunal remains in these shell middens can be related to the duration of human occupations on the coast. This question is based on the idea that people staying in the same settlement for several seasons can explore the surrounding area in greater detail. In this paper we observe that the diversity of faunal remains, including seashells, is not only dependent on the way of life of coastal people and settlement duration. It also affects other factors, such as the accessibility of more or less diversified environments and their resources in the vicinity of settlements and the degree of adaptability of humans exploiting similar resources.
\end{abstract}

Key-words: Mesolithic, Shell midden, occupation, maritime hunter-gatherers

\section{Introduction}

One of most fundamental criteria defining Mesolithic populations is the way of life of hunter-gatherers. In archaeology, this has classically given rise to a rather negative image of Mesolithic populations, as well as the hypothesis of seasonal (nomadic) settlement. This hypothesis was challenged from the outset by the notion that early farmers stabilized their settlement mode (sedentary versus permanent dwellings) in order to cultivate part of their food (Zvelebil, 1996). However, a review of the archaeological literature shows little evidence of this stabilization for Mesolithic people for more than one season. Indeed, while there are some "snapshot" indications of the presence of Mesolithic groups on the coastal belt, such evidence remains almost non-existent for Neolithic populations. However, we could infer that the presence of certain Neolithic populations close to the coast was justified by the presence of certain marine resources that were easier to exploit on a seasonal basis. Such is the case for salt, algae in island environments or certain migratory food resources in estuaries (Barber, 1982). Moreover, ethnographic examples have profoundly modified the image of an egalitarian nomadic community of hunter-gatherers (Testart, 1982). But where is the archaeological evidence for the presumed presence of populations for more than one season?

We wish to address this question by focussing on Mesolithic marine shellfish-consuming populations on the European Atlantic coast.

First of all, we present a review of the literature, in the aim of summarizing the published data on issues relating to occupation for the whole set of listed Mesolithic coastal sites. The data used are extracted from an unpublished database which lists all the published archaeological components of Mesolithic shell middens. Based on these data, we address several questions. Do the published studies of Mesolithic shell middens take settlement modes into consideration? If so, what criteria are these based on? When (in which season) were sites occupied? Does the diversity of animal taxa reflect the duration of occupation (more than one season, more than one year...) at a given site? In the same way, could the number of consumed mollusc species be related to a certain degree of stabilization of these coastal populations?

We use the database presented here to address these questions in general terms, and then consider the data from recently excavated archaeological sites. The current trend in archaeology aims at intensively excavating or even re-excavating sites in marine environments, namely Mesolithic shell middens, thus leading to new interpretations 
of these deposits. The diversity of the exploited resources can also be discussed in greater depth here since the detailed nature of the excavations and the specialization of archaeological disciplines allow us to "detect" archaeological remains that were not brought to light by previous excavations.

\section{Materials and methods}

We make use of two sources to discuss the settlement mode of Mesolithic populations. The first source is the bibliography listed in the database succinctly presented below. Based on this first approach, we draw up an assessment of our knowledge of the settlement modes of Mesolithic populations along the European Atlantic coast. The second source of information is based on two archaeological sites: Beg-er-Vil (France) and Cabeço da Amoreira (Portugal). These two recently excavated Mesolithic sites enable us to take stock of the archaeological data currently used to discuss the settlement modes of these hunter-gatherer populations.

\subsection{Database}




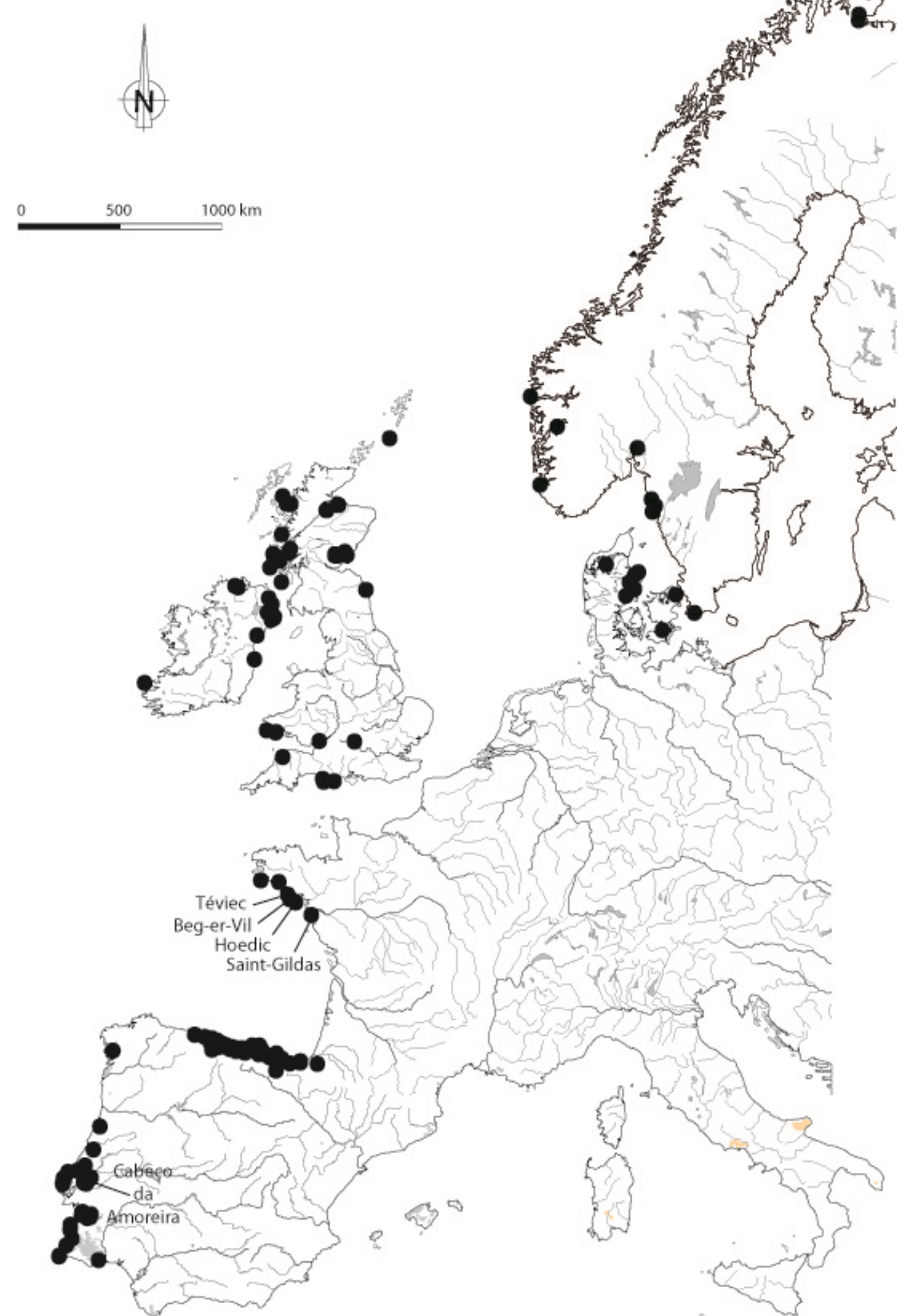

Fig. 1 - Map of the Mesolithic shell middens listed in the database and location of the sites mentioned in the text

In 2004, a database was created in order to summarize information on Neolithization. This database was intended to be expandable and is amended regularly in the light of new publications. More than 400 bibliographic references responded positively, which allowed us to add data to the existing information. Unfortunately, it is impossible to mention all the references used in this paper. Here we will describe in detail the 
contents of the database. It lists the archaeological components of all the Mesolithic and Neolithic sites along the European Atlantic arc where molluscs were consumed (extending from Norway to the south of Portugal). This database is composed of several elements. The period (Mesolithic or Neolithic) attributed to a given site is that mentioned in the most recent publication concerning the site. The evidence supporting these attributions proves to be very varied: absence of domestic animals or cereals, lithic industry, malacofaunal composition and radiocarbon dating. We deliberately used the latest published data for the attribution of the period as criteria change regularly and vary from country to country. The raw dates (shell, wood, animal or human bone... with detailed species when they are specified) used for radiocarbon dates are also mentioned along with references to facilitate recalibration if necessary. The dimensions of shell middens are also listed, along with the proportion excavated, as well as the excavation techniques (with or without sieving), specifying the mesh-size used for sieving when published information is available. The published data relating to the mode of occupation or residence (seasonal, permanent, recurrent or limited in time; based on the size of the site, on its stratigraphy, on the quantity of food waste, on the diversity of lithic tools, on the presence of cemeteries, on sclerochronological analyses on shells or otoliths...), subsistence modes (hunting, fishing, gathering, breeding, farming) and specific characteristics of the site are also reported, while taking care to note the archaeological data on which researchers' interpretations are based. In addition, all the artefacts making up these accumulations are listed: plants (seeds, charcoal, phytoliths, etc.), animals (terrestrial and marine mammals, avifauna, amphibians, reptiles, fish, marine and terrestrial molluscs, crustaceans, sea urchins), as well as lithic and ceramic materials. For the fauna and flora, the species present as well as their relative abundance are noted when this information is available. As regards the lithic industry, the types of tools and their relative abundance are recorded. For ceramics, the types of decoration and quantities of items are also noted. In this way, 400 shell deposits are described including 248 attributed to the Mesolithic (Fig. 1), 75 to the Mesolithic and Neolithic combined and 77 to the Neolithic. When several phases of occupation can be identified with some being assigned to the Mesolithic and others to the Neolithic, each chronological entity is noted as a distinct site. The sites listed as belonging to both the Mesolithic and the Neolithic correspond to sites where the archaeological composition of the various phases of occupation are not differentiated. The database is cross-examined as part of this study to determine the proportion of Mesolithic shelly deposits where published information on residence is available, and, if so, on what criteria. Many of these shell middens were excavated in the past, others are only known from prospecting. Through the example of two recently excavated sites, we aim to reconsider the criteria used to determine whether it is possible to assess occupation continuity at certain sites.

\subsection{Shell middens of Beg-er-Vil and Cabeço da Amoreira}

Two shell middens were selected in a second approach to address the occupation mode of maritime populations of hunter-gatherers during the Mesolithic. This choice is based on several common denominators: both sites are currently being re-excavated using similar techniques. Both are dated to the late Mesolithic where the question of a possible continuity of occupation has become even more crucial.

Beg-er-Vil was discovered in the 1970s by G. Bernier (Bernier, 1970; cited in Kayser, 1987). This discovery is related to the erosion of the rocky coast on which the site is located (Marchand et al. in press). The site was then

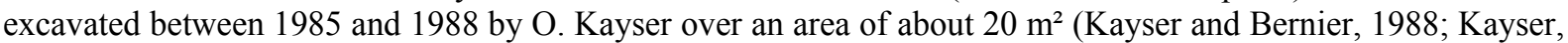
1992). Following a rapid resumption of erosion, new excavations have been in progress since 2012 under the scientific supervision of G. Marchand and C. Dupont (Marchand and Dupont, 2014). It would appear that $100 \mathrm{~m}^{2}$ of this shell accumulation have now been observed (Kayser, 1990). However, it remains very difficult to evaluate the original area covered by the deposit due to the intense erosion of the coastline in this region, as well as the dissolution of part of the initial shell material and the presence of the dune masking the site, which ranges in thickness from 0.30 to $1.60 \mathrm{~m}$ (Marchand and Dupont, 2014). The chronological attribution of the site is corroborated by radiocarbon dating results. "Eight new dates have been obtained from short-lived samples (burnt fruit, roe deer bone and twigs or brushwood) which have enabled us to place the formation of this archaeological layer of human origin at the beginning of the $7^{\text {th }}$ millennium" (Marchand and Dupont, 2014). This site is associated with the Mesolithic on account of several factors: the absence of domesticated mammals, the absence of cereals, the dating results and the presence of a lithic industry compatible with the Mesolithic of the Brittany region.

The shell level is approximately $0.50 \mathrm{~m}$ thick. The various excavation campaigns have made it possible to observe several anthropic structures: a layer of burnt stone associated with oysters in the unit containing the shell midden, a hearth and pits dug from the shell level down into the substratum (Marchand and Dupont, 2014). 
Unlike the famous sites of Téviec and Hoedic discovered in the same area, and in the current state of research, burials are absent from this human occupation. This refuse zone is made up of abundant and varied food remains (molluscs, fish, crabs, birds, mammals, etc.) and flint knapping waste. Except for charcoal and some rare seeds, plants seem to have been poorly preserved within this accumulation.

During excavations in the 1980s, the sediments of the refuse heap were sieved without being analysed. Their study was resumed following wet sieving with mesh sizes of 1 and $5 \mathrm{~mm}$. Since the renewed excavations in 2012, the sediments of this shell level have been sieved with water (using sea water and rinsing with fresh water) using mesh sizes of 2 and $4 \mathrm{~mm}$ (Dupont and Bicho, 2015). The entirety of the sieve residue is dry sieved to recover the maximum amount of information from these zones occupied by human groups. A prolonged period of occupation has been proposed for this site, but without any proof of its continuity (Dupont et al. 2009). According to the model of economic organization along the French coastal fringe during the Mesolithic, Beg-erVil can be classified as a base camp with varied activities, as opposed to outlying stations with less varied activities and undoubtedly short durations of occupation (Dupont and Marchand, 2008).

The geographical position of the Cabeço da Amoreira shell midden is different from that of Beg-er-Vil with respect to marine influence. It is located along the River Muge inland from the coast. In contrast to Beg-er-Vil, which is still subject to the action of the sea, Cabeço da Amoreira is currently cut off from marine influences. During the Mesolithic, however, the latter site was subject to marine influence, probably in the vicinity of vast mudflats (van der Schriek et al. 2008). Discovered by Carlos Ribeiro and Pereira da Costa in 1863 (Ribeiro, 1884), the site has been excavated several times by different teams: F. Paula de Oliveira between 1884 and 1885, Mende Corrêa, Serpa Pinto and Santos Junior from 1930 to 1933, Jean Roche and Veiga Ferreira from 1952 to 1965 (Zbyszewski et al., 1980-1981) and José Rolão from 1998 to 2001 (Rolão et al., 2006). Since 2008, excavations have been resumed by Nuno Bicho (Bicho et al. 2011). The surface area of the shell heap is evaluated at 14,000 $\mathrm{m}^{2}$ (Cunha and Cardoso, 2001). The chronological attribution of the site is corroborated by radiocarbon dating. Although there is evidence for several occupations, the shell midden layers were deposited between ca. 7700 and 7600 yrs cal BP (2D) (Bicho et al. 2013). In addition to dating, several other factors associate this shell midden with the Mesolithic: the absence of domesticated mammals, the absence of cereals and the presence of a lithic industry compatible with the Mesolithic typology of the Muge complex.

The currently visible part of the deposit is ca. $60 \mathrm{~m}$ in diameter and nearly $3.5 \mathrm{~m}$ high at the centre (Bicho et al. 2011). Habitat structures have been observed inside the shell midden, including hearths, postholes and pits. Unlike at Beg-er-Vil, burials are associated with the Cabeço da Amoreira shell midden. The refuse zone is made up of abundant and varied food remains (molluses, fish, crabs, birds, mammals, etc.) and charcoal.

As with the Beg-er-Vil site, in spite of sieving during the successive excavations, the sieve residues have not been completely sorted. Often, only the most striking items were extracted from the sieve residue (ornaments, lithic materials, bones), and this operation was carried out directly in the field. The sieving protocol undertaken since 2011 for Cabeço da Amoreira is similar to that applied in Brittany. All the sediments are dry sieved using two screens, with mesh sizes of $6 \mathrm{~mm}$ and $2 \mathrm{~mm}$ (Bicho et al. 2011). The largest elements are extracted during the excavation and all the remaining sieve residues are then sorted in the laboratory. The duration of occupation for this shell midden is unknown, but is likely to have been long (Dupont and Bicho, 2015).

\section{Results and discussion}

First of all, a review of the mode of residence of Mesolithic maritime populations along the European Atlantic seaboard was carried out using the database. The database highlights a major bias: the geographical distribution of the sites is heterogeneous (Fig. 1). Site distribution is largely controlled by a whole range of phenomena accompanying the latest marine transgression (Dupont 2006, pp.7-8; Gutiérrez-Zugasti et al. 2011). In this way, the rise in sea level led to the erosion of the most exposed coasts, the burial of other zones beneath several metres of mud or sand, as well as the immersion of certain Mesolithic coasts. For example, the coasts of the South of France and the North of Portugal are covered by sand dunes which mask the old shoreline. This bias should be taken into account considering that we can only observe part of coastal Mesolithic occupations, and clearly limits the interpretation of data.

A total of 248 Mesolithic shell middens are listed (Fig. 1). Issues relating to occupation residence are only mentioned in $19 \%$ of these cases (Fig. 2). While this proportion appears to be very low, it can be partly explained by the fact that some of the sites are only known from prospection and the long-established investigation of certain excavations. In addition, the underlying assumption that hunter-gatherers were mainly nomads could also have led certain researchers to elude the question in the past. Moreover, the results of this review are well contrasted when we consider the permanence of the occupation. For $22 \%$ of the 46 Mesolithic sites (Fig. 2), 
occupation duration is unknown, while temporary camps are evoked for $50 \%$ of the sites. However, the possible permanence of these settlements is proposed for $28 \%$ of the 46 Mesolithic sites. This last statistic remains high for populations entirely dependent on resources provided by nature. How should we interpret such a high proportion? It could be related to a bias in the representativeness of archaeological sites. For example, sites with a longer duration of occupation could correspond to sites where anthropic activities produced greater amounts of waste, thus making them more visible in the coastal landscape. If we only consider the criteria used to diagnose the occupation mode of populations, we observe a shortcoming in the published data. The criteria used to identify the suggested hypotheses are absent for $16 \%$ of the sites where an occupation mode is proposed (no permanence/possible permanence). This proportion is high considering the implications of the mode of occupation on the organization of hunter-gatherer populations. Unfortunately, the diverse archaeological disciplines are rarely applied to a same site and it is not so easy to recapitulate the occupation mode of these Mesolithic populations for the whole Atlantic façade. For sites where the original data sources for models of economic organization are published, 12 principal criteria can be identified (Fig. 2: source of occupation). Some of them are used individually, whereas others are combined in publications.

For example, some authors consider the shell midden more in terms of a single habitat. Thus, if the overall surface area of a midden is extensive, this is used to back up the hypothesis of a permanent occupation (Rolão, 1999). This type of result remains contentious in the absence of meticulous excavations, since multiple excavations carried out on these shell levels sometimes reveal complex stratigraphies which are far from compatible with constant occupation (Arnaud, 1987; Bicho et al. 2013; Roksandic et al. 2014). In some cases, this same stratigraphy is studied in great detail to determine if the shell midden was abandoned during its formation (Merchant et al. in press). Dating results are also used to define the periods of occupation of human groups at certain sites (O' Sullivan and Breen, 2011). 

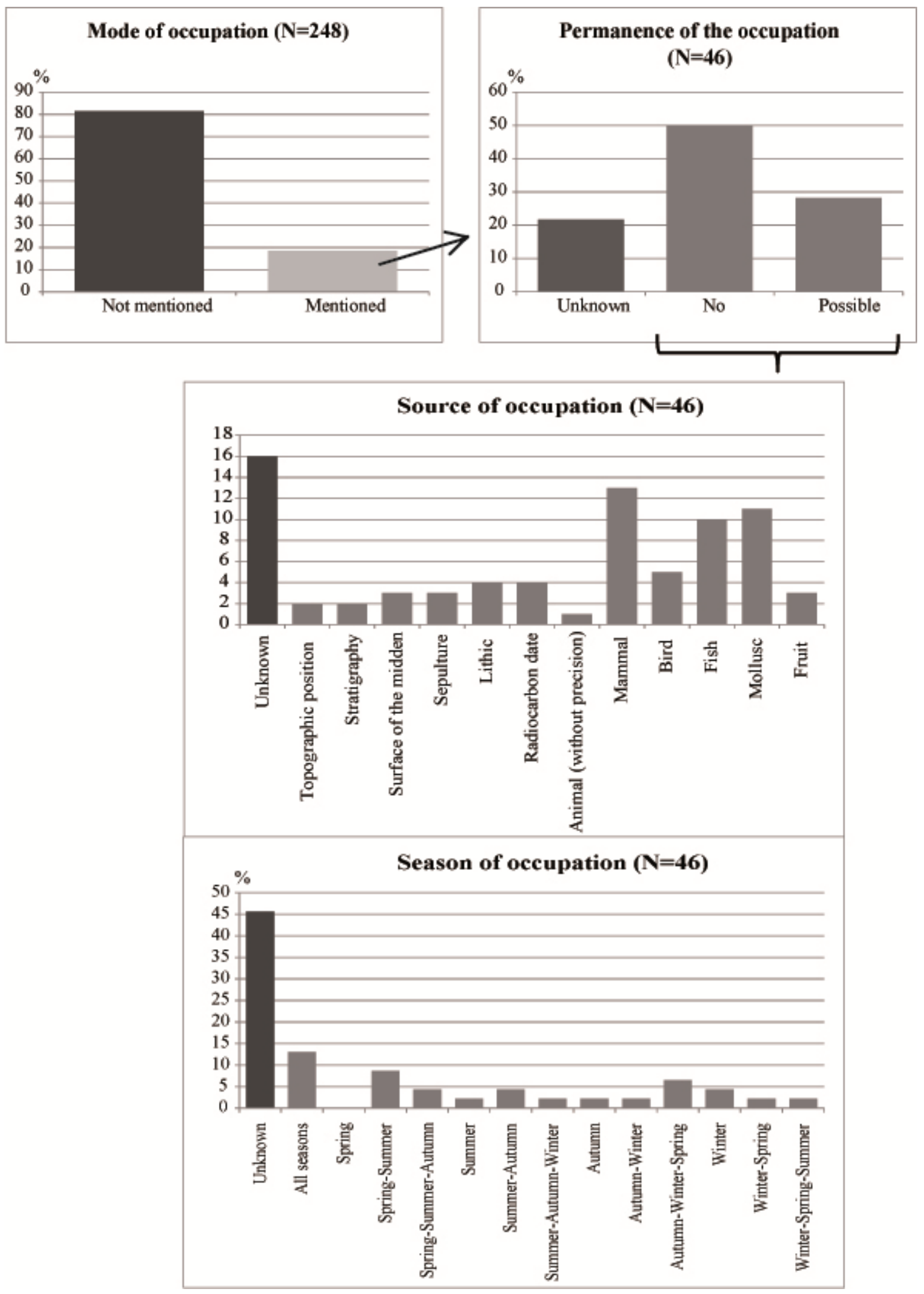

Fig. 2 - Summary of literature concerning the mode of occupation of coastal shellfish-consuming Mesolithic populations with sources of criteria used to define the model of economic organization

Other authors take into account the diversity of lithic components (Valente and Carvalho, 2009) or the presence of structures such as hearths or burials (Lubell et al. 1994; Cunha and Cardoso, 2001; Valente and Carvalho, 
2009). The accessibility of animal resources is also used, based on current animal ethology, as well as the definition of the season of capture of certain species, with methods such as sclerochronology (Indrelid, 1978; Mannino and Thomas, 2007, Schaller Ahrberg, 2007; Gutiérrez Zugati, 2009; Carter, 2009; Dupont et al. 2009; Mannino and Thomas, 2009). Biases may arise on account of the fact that animal behaviour could have evolved since the Mesolithic in response to climatic variations, among other factors. In addition, periods of accessibility to food resources do not necessarily coincide with the presence of humans at the site. Some of the resources may have been stored or prepared. The storage of dried fruit, such as hazelnuts, is widespread but cannot be envisaged for the consumption of fruit with a short storage life, such as the wild pear. The transformation of fresh products into processed products (by drying, for example) could delay their consumption, which would therefore offset the information concerning human occupation. Nonetheless, most of these animal taxa are restricted to the marine environment (birds, shellfish, crabs and fish) and were generally consumed immediately by the coastal populations. Clearly, each of the criteria presented here has its drawbacks. This explains the cautious approach of archaeologists who almost unanimously evoke the "possible" permanence of habitats. The higher the diversity of the observed faunas, the more we are able to link up periods of resource accessibility to extend the snapshots of the presence of these coastal populations on the coast. Unfortunately, the whole range of archaeological disciplines is not systematically applied. After this rather negative evaluation of the archaeological resources used to define Mesolithic population occupations, we needed to examine the archaeozoological data in order to assess whether this diversity could reflect the more or less extended presence of humans near the coast during the Mesolithic.

One of questions addressed here is also to determine whether the diversity of the exploited marine resources is related to the duration of human occupation on a site. For example, we could imagine that a short duration of occupation on the coast might enable the populations to exploit only the most visible and accessible resources, whereas a human population established for a more long term occupation would have time to explore all the environmental niches around the site. In Fig. 3, we compare the diversity of animal taxa (marine molluscs, fish, birds, crabs, mammals, terrestrial mammals, sea urchins, crabs, etc.) between Mesolithic and Neolithic sites along the French Atlantic seaboard. The x-axis coordinates represent the number of taxonomic classes identified in the shell middens (for example, 1 indicates the presence of shellfish alone, while 2 indicates the presence of shellfish associated with another animal class such as birds or mammals, and so on). This diagram shows that there is no overall difference between the diversity of animal classes exploited during the Mesolithic and the Neolithic along the European Atlantic seaboard (Fig. 3). For each economic system, whether it is based on hunting, gathering, fishing or breeding, the diversity of the animal classes used is very heterogeneous and varies from 1 to 6. Thus, there does not appear to be any direct link between the diversity of the exploited animal classes and the duration of occupation of the coastal sites. This variability can be masked by the diversity of human behaviours and circumstances. In the following discussion, we revisit the case studies described above.

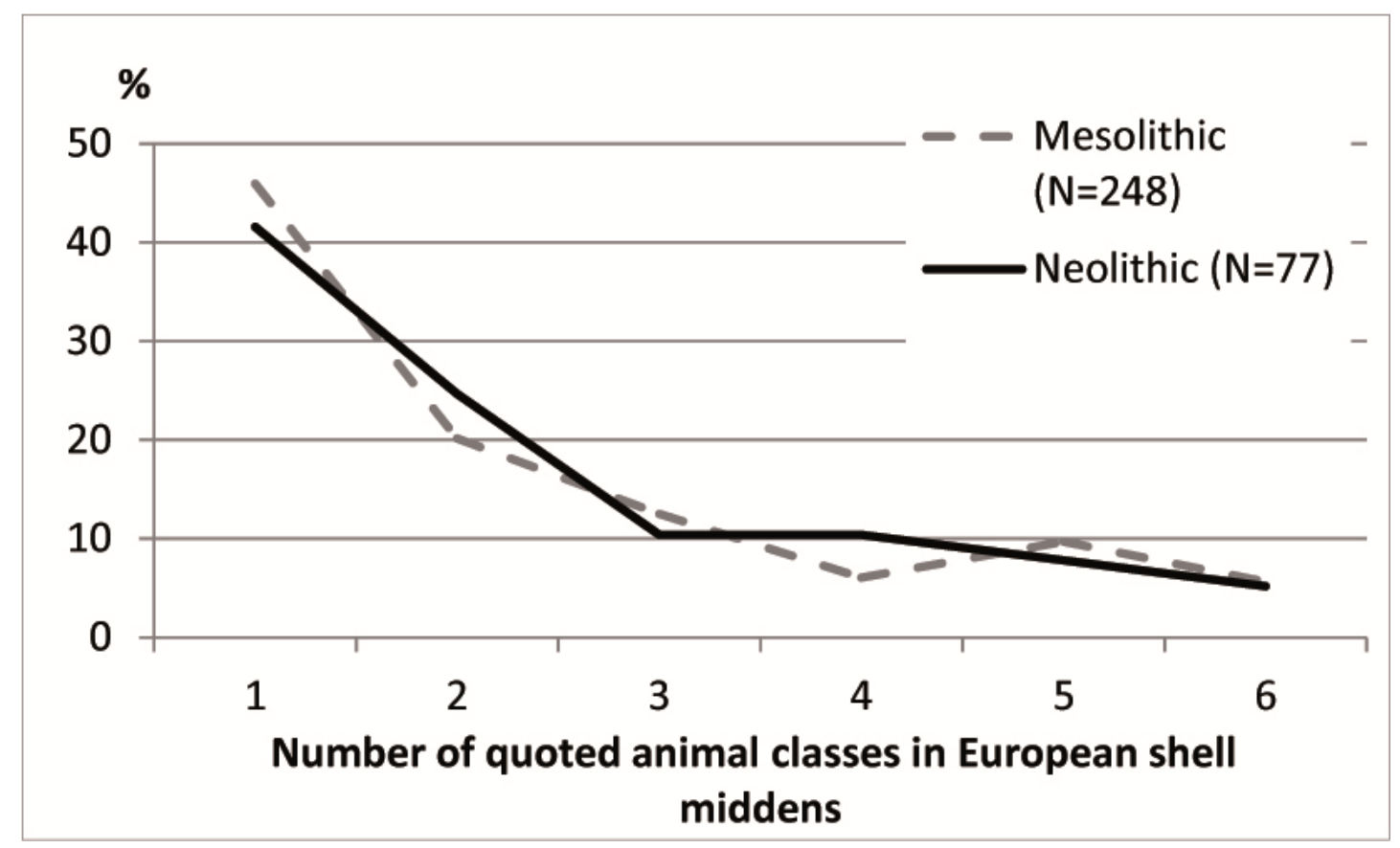

Fig. 3 - Number of animal classes described in Mesolithic and

Neolithic European shell middens 
In the presentation of these case studies, we mentioned that the Beg-er-Vil site can be incorporated into an established model of economic organization in France (Dupont and Marchand, 2008), as it is classified as a base camp with prolonged occupation. The question of diversity is a crucial factor in this classification. Indeed, the broad range of animal classes exploited at Beg-er-Vil ( 6 animal classes represented) implies a wider exploitation of the environment. In the same way, when considering mollusc species, it is necessary to include 5 additional species to obtain $90 \%$ of the total MNI of seashells. Nine species represent more than 1\%: Mytilus edulis, Cerastoderma edule, Patella sp., Littorina littorea, Phorcus lineatus, Ruditapes decussatus, Nucella lapillus, Ostrea edulis and Scrobicularia plana; Fig. 4). According to the sites incorporated in the database, 4.4 mollusc species represent on average more than $1 \%$ of the total MNI in Mesolithic shell middens. Thus, Beg-er-Vil is highly diversified in terms of the exploited species. The percentage of the total MNI and the abundance of these species demonstrate their use as food resources and their deliberate harvesting (Fig. 4). The gathering of these species in the vicinity of the site requires an unquestionable knowledge of the territory surrounding the habitat. These species also reflect the exploitation of three types of substratum from environments accessible less than 5 $\mathrm{km}$ from the shell midden, with a strong contribution from the rocky environment. In the model of economic organization for the French Atlantic coast, Beg-er-Vil clearly contrasts with outlying sites with very short durations of occupation. The site of Saint-Gildas $1 \mathrm{~b}$ belongs to this latter occupation category, with only one animal class making up the diet: molluscs. No other animal or plant remains have been found there. Two mollusc species are represented at Saint-Gildas 1b, accounting for more than $1 \%$ of the total MNI (with Scrobicularia plana making up $95 \%$ and Patella sp. $2 \%$ out of a total MNI of 217). The muddy environment at this site was largely exploited, along with very small proportions of molluscs from the rocky substratum. Thus, for these two examples in France, as well as other archaeological criteria (Dupont and Marchand, 2008), the diversity as well as the number of intentionally exploited animal classes and mollusc species seems to be an index of the duration of occupation of the populations using these sites. For Beg-er-Vil, this hypothesis is supported by the combined accessibility of all the discovered food resources all year round (Dupont et al. 2009). But with the example of Cabeço da Amoreira, we will see that this schema is not as simple as it seems. 

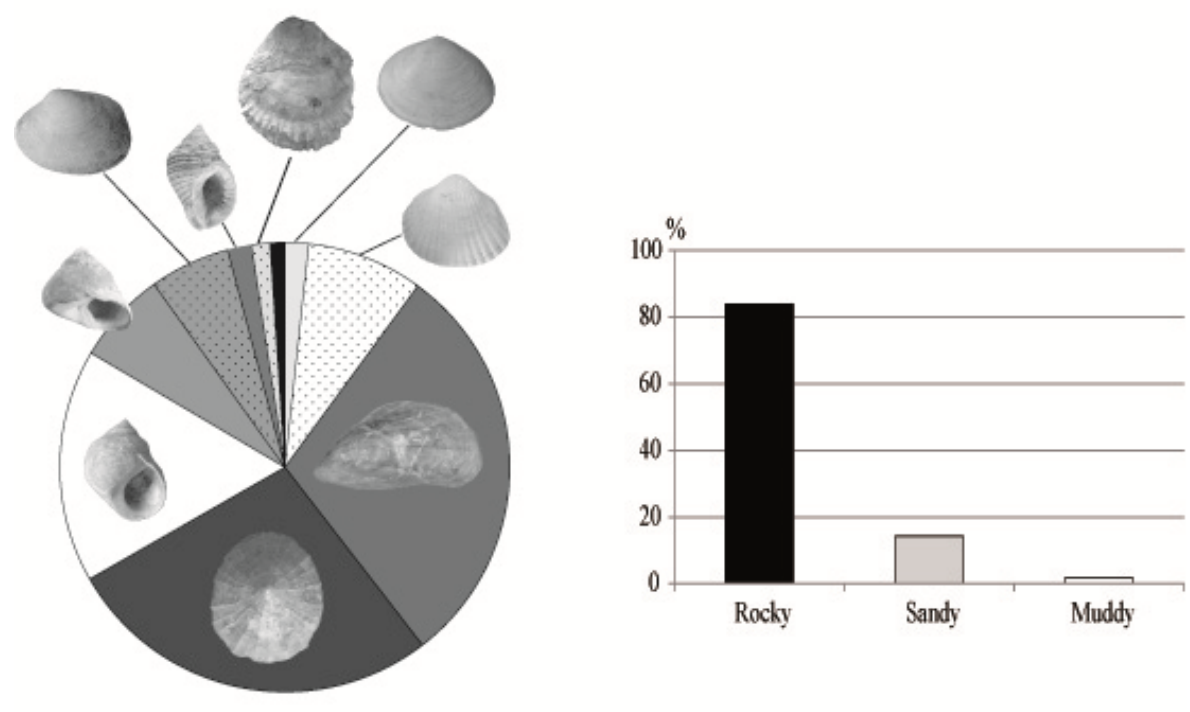

Cabeço da Amoreira (MNI = 93 856)
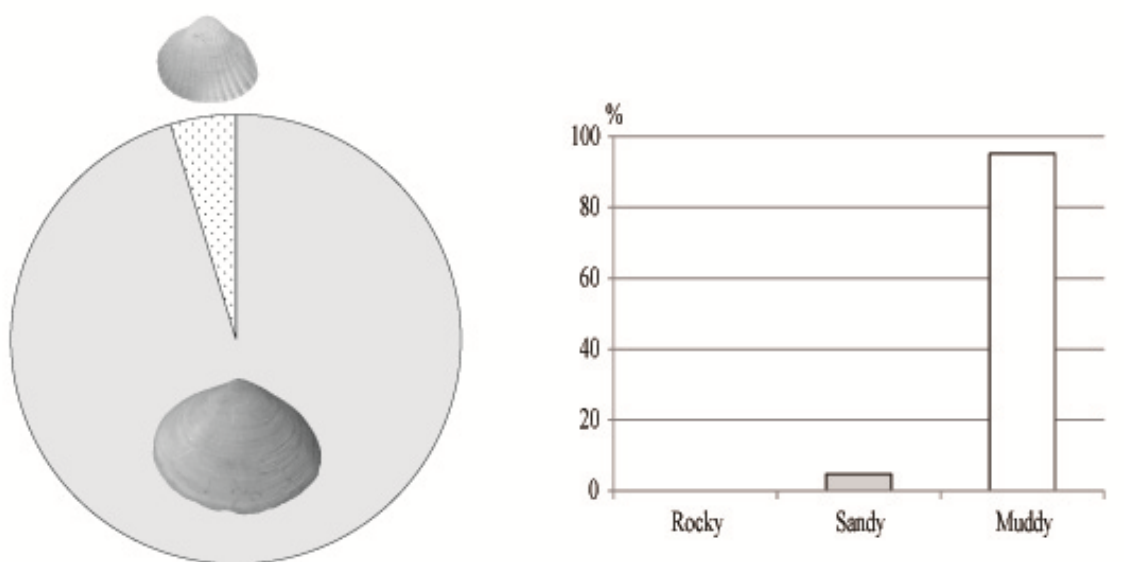

Figure 4 - Malacofaunal distribution of the sites of Beg-er-Vil and Cabeço da Amoreira and their original substrata

Having recently studied the marine invertebrates of Cabeço da Amoreira using similar techniques to those used at Beg-er-Vil, it seems appropriate to compare these sites from the point of view of taxonomic class diversity and malacofaunal distribution. This comparison is also justified by the fact that archaeologists propose a long occupation duration for Cabeço da Amoreira (Dupont and Bicho, 2015). Moreover, in contrast to Beg-er-Vil, the Portuguese site was located close to an estuary during its exploitation (van der Schriek et al. 2008). In the case of Beg-er-Vil, the number of described animal classes (6) indicates very high diversity. On the other hand, at Cabeço da Amoreira, only two mollusc species account for more than $1 \%$ of the total MNI (Scrobicularia plana and Cerastoderma edule; Fig. 4). This low number of species is comparable to the results obtained for the site of Saint-Gildas. However, this poor diversity represents the environments accessible within a $5 \mathrm{~km}$ radius around the site. Thus, even if the site of Cabeço da Amoreira displays evidence of a prolonged occupation, the nearby environmental constraints limited the possibility of exploiting a varied number of molluscs.

\section{Conclusions}


It is difficult to investigate the occupation mode (nomadic or permanent/sedentary) and duration (all year round, seasonal...) of the Mesolithic shellfish-consuming populations who settled along the European Atlantic coast. Many factors interfere with the overall vision of the archaeologist. Even the distribution of archaeological sites on the coast is largely shaped by the effects of tidal fluctuations. Moreover, a review of the literature shows that the question of occupation mode has not been systematically addressed for all the sites. In cases where this issue is discussed, certain authors acknowledge their inability to identify any occupation traces of these huntergatherer populations, due to the lack of evidence or preservation of the artefacts. Even if new lines of research are opened up by addressing the occupation mode of Mesolithic hunter-gatherers along the European Atlantic seaboard, such an approach would tend to "smooth out" the data. Various authors have made use of at least 12 different criteria to define the season of occupation of Mesolithic coastal habitats. Sometimes these criteria are combined, sometimes not. Therefore, the heterogeneity of the published data makes a synopsis of the topic difficult. The results obtained from this approach show various occupation modes at Mesolithic sites during all seasons in a more or less occasional manner. On account of the difficulties involved in describing the permanence of a settlement, archaeologists are cautious in publications concerning the topic and many of them merely allude to the "possible" permanence of the presence of Mesolithic people near the sea.

By studying the diversity of exploited faunas, we can obtain an index of the adaptation of human populations with respect to their nearby environments. Such an index is provided here by the number of animal classes represented at the scale of the European Atlantic seaboard. This approach shows that scenarios are very variable and that the representation of sites tends to decrease as the number of exploited animal classes increases. Two major variables should be taken in account to explain the diversity of scenarios and the fact that the range of exploited faunas cannot be used as an indication of occupation duration: the accessible environments and the resources they procure and the behaviour of coastal populations. If maritime people only have access to one kind of environment, they seem to be able to adapt to this unique environment and to the low faunal diversity. It appears that in spite of this low diversity they can establish long occupations (spanning more than one season). This is what we seem to clearly observe in Cabeço da Amoreira. As for the second variable, i.e., the importance of the diversity of human behaviour in the same environment, we clearly observe that Mesolithic people on French coasts with access to a large diversity of marine environments explored and exploited the diverse resources in the nearby environment (Dupont, 2006). During the Neolithic, the appearance of predicable resources like cereals and cattle completely alters the behaviour of coastal populations. Unlike Mesolithic people collecting very diverse shell types, Neolithic populations mainly select two mollusc species among the more accessible species at low tide, for example (Dupont 2006).

It is always fundamental to return to the scale of an archaeological site to improve our understanding of the behaviours of Mesolithic coastal populations. Thus, for sites in the course of excavation at Beg-er-Vil and Cabeço da Amoreira, prolonged occupation by Mesolithic populations seems to be corroborated by the diversity of the animal classes exploited, as well as other previously exposed criteria (stratigraphy, presence of structures, burials, diversity of lithic tools...). Both of these sites show a taxonomic diversity of 6 at a class level. In the same way, the number of exploited shellfish species could very well increase with the duration of occupation. Prolonged occupation would allow human groups to explore all the niches along the foreshore. This latter scenario could well be applied to Beg-er-Vil, where 9 marine mollusc species were harvested in environments close to the site. Among these mollusc species, we note the presence of the dog whelk Nucella lapillus. Along with the sites of Oronsay (Scotland), this occurrence represents one of the rare traces of the consumption of this gastropod (Mellars, 1987). At Beg-er-Vil, shellfish were harvested from rocks, sands and mudflats. Species diversity falls to 2 for the Mesolithic shell midden at Cabeço da Amoreira in Portugal. Should we conclude from this that occupation duration was short in spite of other archaeological evidence from the site indicating a wellestablished long-term coastal population? We consider that such a conclusion is unfounded. The relatively low number of exploited molluscs seems to be constrained by the rare occurrence of environments with diverse species that could be used as food resources. Thus, although the Cabeço da Amoreira example shows that environmental pressure is high, this did not prevent the stabilization of this Mesolithic population throughout the course of time.

The permanent nature of occupation can be raised but is difficult to prove for the European Atlantic seaboard as a whole as well as for the analysis of individual sites. The concept of occupation duration is a problematic issue. Occupations can be intermittent over a relatively long period of time and continuity is hard to demonstrate. The diversity of the exploited resources is not directly related to the duration of occupation: it is often necessary to address this issue case by case. Two major parameters can interfere with the combination of diversity and occupation duration: the accessibility of resources in the vicinity of the site and human behaviour (such as cultural preferences) linked to the high diversity of ways of life of coastal human populations. 
The author would like to thank the archaeologists who contribute to the excavation of shell middens with adapted methods. The first version of the database was supported by the project "Action Concertée Incitative jeunes chercheurs 'La néolithisation de la façade atlantique de l'Europe : interactions culturelles, transferts techniques, implications des milieux naturels' (Supervisor: G. Marchand / UMR 6566) (2002-2005)". We also thank the two anonymous reviewers who helped to improve this paper.

\section{References}

Arnaud, J.-M, 1987. Os concheiros mesoliticos dos vales do Tejo e Sado: semelhanças e differenças. Arqueologia 15, 53-64.

Barber, R., 1982. The Wheeler's site: A Specialized Shellfish Processing Station on The Merrimack River. Peabody Museum Monograph 7, Harvard University, Cambridge, Massachusetts.

Bicho, N., Cascalheira, J., Marreiros, J., Pereira, T., 2011. The 2008-2010 excavations of Cabeço da Amoreira, Muge, Portugal. Mesolithic Miscellany 21-2, 3-13.

Bicho, N., Cascalheira, J., Marreiros, J., Pereira, T., Dias R., 2013. Chronology of the Mesolithic occupation of the Muge valley, central Portugal: The case of Cabeço da Amoreira. Quaternary International 308-309, 130-139.

Carter, R., 2009. 18. One pig does not a winter make. New seasonal evidence at the Early Mesolithic sites of Holmeggard and Mullerup and the Late Mesolithic site of Ertebølle in Denmark. In: McCartan, S., Schulting, R., Warren, G., Woodman, P. (Eds.), Mesolithic Horizons, Papers presented at the 7th International Conference on the Mesolithic in Europe, Belfast 2005. Oxbow, Oxford, pp. 115-121.

Cunha, E., Cardoso, F., 2001. The osteological series from Cabeço da Amoreira (Muge, Portugal). Bulletins et mémoires de la Société d'Anthropologie de Paris 13/3-4, 323-333.

Dupont, C., 2006. La malacofaune de sites mésolithiques et néolithiques de la façade atlantique de la France: Contribution à l'économie et à l'identité culturelle des groupes concernés. British Archaeological Reports International Series 1571 Archeopress, Oxford.

Dupont, C., Bicho, N., 2015. Marine invertebrates and models of economic organization of the coastal zone during the Mesolithic: French and Portuguese examples. In: Bicho, N., Detry, C., Price, T. D., Cunha, E. (Ed.), Muge 150th, The 150th Anniversary of the Discovery of the Mesolithic Shellmiddens. Vol.1. Cambridge Scholars Publishing. Newcastle, pp. 89-103.

Dupont, C., Marchand, G., 2008. Coastal exploitation in the Mesolithic of western France: la Pointe Saint-Gildas (Préfailles). Environmental Archaeology 13-2, 143-152.

Dupont, C., Tresset, A., Desse-Berset, N., Gruet, Y., Marchand, G., Schulting, R., 2009. Harvesting the seashores in the Late Mesolithic of north-western Europe. A view from Brittany? Journal of World Prehistory 22-2, 93-111.

Gutiérrez Zugati, F.I., 2009. An examination of Mesolithic shellfishing activities in the lower Asón river basin (Cantabira, Spain). In: McCartan, S., Schulting, R., Warren, G., Woodman, P. (Eds.), Mesolithic Horizons, Papers presented at the 7th International Conference on the Mesolithic in Europe, Belfast 2005, pp. 161-166.

Gutiérrez-Zugasti, F.I.,Andersen, S.H., Araujo, A.C., Dupont, C., Milner, N., Monge-Soares, A.M., 2011. Shell midden research in Atlantic Europe: state of art, research problems and perspectives for the future. Quaternary International, 239, 70-85.

Indrelid, S., 1978. Mesolithic economy and settlement patterns in Norway. In: Mellars, P. (Ed.), The early Postglacial Settlement of Northern Europe, An Ecological Perspective. Duckworth, London, pp. 147-177. 
Kayser, O., 1987. Beg-er-Vil : Quiberon (Morbihan), Campagne 1987, Sauvetage programme n ${ }^{\circ} 1400$ site $^{\circ}{ }^{\circ} 56$ 186 007, Programme 24.

Kayser, O., 1990. Beg-er-vil. Gallia information, 64.

Kayser, O., 1992. Les industries lithiques de la fin du Mésolithique en Armorique. In: Leroux, C.T. (Ed.), Paysans et bâtisseurs, l'émergence du Néolithique atlantique et les origines du mégalithisme, Actes du XVIIème colloque interrégional sur le Néolithique, Vannes, 1990, Revue Archéologique de l'Ouest Supplément 5, pp. $117-124$.

Kayser, O., Bernier, G., 1988. Nouveaux objets décorés du Mésolithique armoricain. Bulletin de la Société Préhistorique Française 85-2, 45-47.

Lubell, D., Jackes, M., Schwarcz, H., Knyf, M., Meiklejohn, C., 1994. The Mesolithic-Neolithic transition in Portugal, Part1 : isotopic and Dental evidence of Diet. Journal of Archaeology Science 21, 201-216.

Mannino, M.A., Thomas, K.D., 2007. Chapter 11, Determining the season of collection of inter-tidal gastropods from $\delta 180$ analysis of shell carbonates: modern analogue data and 'intertidal analysis' of data from archaeological shells. In: Milner, N., Craig, O.E., Bailey, G.N. (Eds.), Shell-Middens in Atlantic Europe, Oxbow books, Oxford, pp. 111-122.

Mannino, M.A., Thomas, K.D., 2009. The strategy of the shoreline? Social ecology of Mesolithic coastal subsistence, with reference to the site of Culverwell, Isle of Portland (southern England). In: McCartan, S., Schulting, R., Warren, G., Woodman, P. (Eds.), Mesolithic Horizons, Papers presented at the 7th International Conference on the Mesolithic in Europe, Belfast 2005. Oxbow, Oxford, pp. 146-151.

Marchand, G., Dupont, C., 2014. Maritime hunter-gatherers of the Atlantic Mesolithic: current archaeological excavations in the shell levels of Beg-er-Vil (Quiberon, Morbihan, France). Mesolithic Miscellany 22-2, 3-9.

Marchand, G., Dupont, C., Delhon, C., Desse-Berset, N., Gruet, Y., Laforge, M., Le Bannier, J.-C., Netter, C., Nukushina, D., Onfray, M., Querré, G., Quesnel, L., Schulting, R., Stéphan, P., Tresset, A., in press. Retour à Beg-er-Vil Nouvelles approches des chasseurs-cueilleurs maritimes de France Atlantique. In: Dupont, C., Marchand, G. (Ed.), Séances de la Société préhistorique française.

Mellars, P., 1987. Oronsay: prehistoric human ecology on a small island. Edinburgh University Press, Edinburgh.

O'Sullivan, A., Breen, C., 2011. Maritime Ireland: an archaeology of coastal communities. The History Press, Stroud.

Ribeiro, C., 1884. Les kjoekkenmoedings de la vallée du Tage. In: Comptes rendus de la IXème session du congrès International d'Anthropologie et d'Archéologie Préhistorique, Typographie de l'académie royale des sciences, Lisbonne, pp. 279-290.

Rolão, J., 1999. Del Wurm final al Holocénico en el Bajo Valle del Tajo (Complejo Arqueológico Mesolítico de Muge). Unpublished Ph.D. dissertation, Universidad de Salamanca, Spain.

Rolão, J. M. F., Joaquinito, A., Gonzaga, M., 2006. O complexo Mesolítico de Muge: novos resultados sobre a ocupação do Cabeço da Amoreira. In: Bicho, N. F., Veríssimo, H. (Eds.), Do Epipaleolítico ao Calcolítico. Centro de Estudos do Património, Faro, pp. 27-41.

Roksandic, M., Mendonça de Souza, S., Eggers, S., Burchell, M., 2014. The Cultural Dynamics of Shell-Matrix Sites. University of New Mexico Press, United States of America. 
Schaller Ahrberg, A., 2007. Fishing for storage: Mesolithic short term fishing for long term consumption. In: Milner, N., Craig, O.E., Bailey, G.N. (Eds.), Shell-Middens in Atlantic Europe. Oxbow books, Oxford, pp. 4653.

Testart, A., 1982. Les chasseurs-cueilleurs ou l'origine des inégalités. Edition de la Société ethnographique, Paris.

Valente, M.J., Carvalho, A.F., 2009. Recent Developments in Early Holocene Hunter-Gatherer Susbsistence and Settlement : a view from southwestern Iberia. In: McCartan, S., Schulting, R., Warren, G., Woodman, P. (Eds.), Mesolithic Horizons, Papers presented at the 7th International Conference on the Mesolithic in Europe, Belfast 2005. Oxbow, Oxford, pp. 312-317.

van der Schriek, T., Passamore, D., Mugica, F., Stenvenson, A., Boomer, I., Rolão, J., 2008. Holocene Paleoecology and floodplain evolution of the Muge tributary, Lower Tagus basin, Portugal. Quaternary International 189, 135-151.

Zbyszewski, G., Penalva, C., da Veiga Ferreira, O., 1980-1981. Découverte d'un instrument préparé sur bois de Cervus elaphus au Cabeço da Amoreira (Muge). Setubal Arqueologica 6-7, 39-45.

Zvelebil, M., 1996. Farmers, Our Ancestors and the Identity of Europe. In: Graves-Brown, P., Jones, S., Gamble, C. (Eds.), Cultural Identity and Archaeology: The Construction of European Communities. Routledge, London, pp. $145-166$. 